\title{
Use of Arabinogalactan Proteins in Coconut (Cocos Nucifera L.) Tissue Culture: An Alternative Approach for Improved Tissue Response
}

\author{
S C Fernando $^{1 *}$, D A D S Samarajeewa ${ }^{2}$, and L G N H K Liyanagedara ${ }^{2}$
}

\begin{abstract}
Arabinogalactan proteins (AGPs) are extra-cellular proteins involved in plant growth and development. The effects of these proteins on in vitro response of different species are well documented. This study assessed for the first time the role of AGPs on tissue culture of coconut, a highly recalcitrant species in vitro. Coconut (Sri Lanka Tall) plumules were cultured in medium containing 2, 4-dichlorophenoxyaceticacid (2,4-D) for callogenesis. Calli were multiplied by subculturing onto freshly prepared callusing medium. Somatic embryos were induced by transferring of calli to medium with $2 / 3$ concentration of initial 2,4-D and matured by subsequent transferring to medium without any hormones. Embryos were converted in the presence of gibberelic acid. Arabic gum (1-50 $\left.\mathrm{mgL}^{-1}\right)$ was used as the main source of AGP. Alternatively, different AGP sources like Larch wood gum, carrot seeds and defatted coconut kernel were also assessed. Arabic gum in callusing medium resulted in early callogenesis from $20-40 \%$ plumules compared to $10 \%$ in the control. However, it did not have a significant effect on final callusing efficiency. Its presence in somatic embryogenesis medium showed a significantly higher mass of embryogenic structures per an embryogenic clump (33.3-50.5mg) when compared to the control $(26.9 \mathrm{mg})$. The best result was obtained at $10 \mathrm{mgL}^{-1}$ Arabic gum. All AGP sources except Larch wood gum had positive effects on somatic embryogenesis. Among them, defatted coconut kernel $\left(25-50 \mathrm{mgL}^{-1}\right)$ showed the best results giving $70 \%$ cultures with embryogenic structures compared to $37 \%$ in control. However, so far, the positive effect of AGP did not reflect in plant regeneration efficiency.
\end{abstract}

Key words: arabinogalactan proteins, coconut, somatic embryogenesis, tissue culture

\footnotetext{
${ }^{1}$ Tissue Culture Division, Coconut Research Institute, Lunuwila, Sri Lanka.

${ }^{2}$ Department of Biotechnology, Faculty of Agriculture and Plantation Management, Wayamba University, Makandura,Gonawila, Sri Lanka.

* Corresponding author: shyamafernando2003@yahoo.com
} 


\section{Introduction}

Arabinogalactan proteins (AGPs) are a heterogeneous group of proteoglycans present in cell walls, plasma membrane and plant secretions and commonly found in culture media (Fincher et al., 1983). Different plant organs contain specific sets of AGPs that are dependent on the developmental stage of the tissue (Pennell et al., 1992). The molecules are involved in the regulation of several important events related to plant growth and development (Wisniewska and Majewska-Sawka, 2007 and references therein). AGPs have also been proven to play an important role in the course of in vitro development of plant cells and tissues (Table 1). Facts summarized in the Table 1 imply that by changing the AGPs of the extracellular matrix of cells in culture, it is possible to alter the development fate of cells.

Clonal propagation of coconut is of importance for speeding up the coconut breeding programmes and true to type propagation of elite mother palms. Due to the limitations pertinent to coconut (Fernando, 2008), it is still considered as a highly recalcitrant plant to in vitro culture. Considering the potential of AGPs recorded in other plants, it can be hypothesized that application of AGPs is an alternative way to improve in vitro response of coconut. So far, this has not been tested in any palm. Thus, the aim of the study was to test whether AGPs improve response of coconut tissues to in vitro culture. This paper presents the preliminary results.

\section{Materials and Methods}

Plant material

Zygotic embryos were collected from mature (12 months after pollination) nuts of coconut (variety Sri Lanka Tall).

\section{Callogenesis}

Zygotic embryos were sterilized in $3 \%$ $(\mathrm{v} / \mathrm{v})$ Clorox for five minutes and rinsed five times with sterile distilled water. Plumules were excised under stereo binocular microscope, crushed and placed on basal medium CRI 72 (Karunaratne and Periyapperuma, 1989) supplemented with $215 \quad \mu \mathrm{M} \quad 2,4-$ dichlorophenoxyacetic acid (2,4-D) and $0.1 \%$ $(\mathrm{w} / \mathrm{v})$ activated charcoal (BDH) for 10 weeks in the dark at $28^{\circ} \mathrm{C}$ to induce callusing. Embryogenic calli were multiplied by subculturing onto the freshly prepared callusing medium.

Somatic embryogenesis

Embryogenic cultures were transferred to the CRI 72 medium supplemented with low $(133 \mu \mathrm{M})$ 2,4-D and incubated for 6 weeks followed by transfer to the same basal medium without hormones for four weeks. Subsequently cultures were maintained in Y3 (Eeuwens, 1978) supplemented with $0.45 \mu \mathrm{M}$ gibberelic acid by subculturing at 4-5 weekly intervals until shoots were developed. The cultures were maintained at $28{ }^{\circ} \mathrm{C}$ in the dark until somatic embryos developed into shoots. Then they were transferred to $16 \mathrm{hr}$ light (PAR; $25 \mu \mathrm{molm}^{-2} \mathrm{~s}^{-1}$ ).

\section{Effect of AGPs}

The effect of AGPs on callogenesis was studied by culturing of plumules in callusing medium supplemented with filter sterilized Arabic gum (AG) (1, 10 and $50 \mathrm{mgL}^{-1}$ ). Embryogenic cultures were transferred to media containing $133 \mu \mathrm{M}$ 2,4-D and AG (1, 10 and 50 $\mathrm{mg} \mathrm{L}^{-1}$ ) to assess the effect of AGPs on induction of embryogenic structures. Finally, the effect of various sources of AGPs on somatic embryogenesis was evaluated by maintaining cultures in low 2,4-D and hormonefree media supplemented with filter sterilized AG (1 and $\left.10 \mathrm{mgL}^{-1}\right)$, Larch wood gum (LW) (1 and $10 \mathrm{mgL}^{-1}$ ), carrot seed powder (CS) (25 and $50 \mathrm{mgL}^{-1}$ ) and defatted coconut kernel (DCK) (25 and $50 \mathrm{mgL}^{-1}$ ).

Data Collection and analysis

Data was collected from 10-15 replicates per treatment. The experiments were repeated at least twice. The number of explants producing callus was counted at two weekly intervals for six weeks. Cultures producing embryogenic structures (Fig. 1a) and total weight of embryogenic structures were recorded to assess the effect of AG on early somatic embryogenesis. Finally, the number of cultures producing somatic embryos (Fig. 1b) was 
Table 1. Role of AGPs on plant tissue culture

\begin{tabular}{|c|c|c|c|}
\hline Species & AGP source & Effect shown & Reference \\
\hline $\begin{array}{l}\text { Daucus } \\
\text { carota } \mathrm{L} .\end{array}$ & Carrot seeds & $\begin{array}{l}\text { - Re-induced embryogenesis in non- } \\
\text { embryogenic cell lines } \\
\text { - Increased embryogenesis in young } \\
\text { cell lines }\end{array}$ & $\begin{array}{l}\text { Kreuger and } \\
\text { Van Holst, } \\
1993\end{array}$ \\
\hline $\begin{array}{l}\text { Daucus } \\
\text { carota } \mathrm{L} .\end{array}$ & Tomato seeds & $\begin{array}{l}\text { - Increased embryogenesis in young } \\
\text { cell lines }\end{array}$ & $\begin{array}{l}\text { Kreuger and } \\
\text { Van Holst, } \\
1993\end{array}$ \\
\hline $\begin{array}{l}\text { Cyclamen } \\
\text { persicum } \mathrm{L} .\end{array}$ & Carrot seeds & $\begin{array}{l}\text { - Increased proembryogenic masses in } \\
\text { cell cultures }\end{array}$ & $\begin{array}{l}\text { Kreuger et al., } \\
1995\end{array}$ \\
\hline $\begin{array}{l}\text { Picea } \\
\text { abies L. }\end{array}$ & $\begin{array}{l}\text { Spruce seeds } \\
\text { Conditioned } \\
\text { medium }\end{array}$ & $\begin{array}{l}\text { - Increased embryogenesis in low } \\
\text { embryogenic cell lines }\end{array}$ & $\begin{array}{l}\text { Egertsdotter } \\
\text { and Van } \\
\text { Arnold, } 1995\end{array}$ \\
\hline $\begin{array}{l}\text { Daucus } \\
\text { carota L. }\end{array}$ & $\begin{array}{l}\text { Carrot seeds } \\
\text { Conditioned } \\
\text { medium }\end{array}$ & $\begin{array}{l}\text { - Increased somatic embryogenesis } \\
\text { from protoplasts. }\end{array}$ & $\begin{array}{l}\text { Van Hengel et } \\
\text { al., } 2001\end{array}$ \\
\hline $\begin{array}{l}\text { Gossypium } \\
\text { hirsutum L. }\end{array}$ & $\begin{array}{l}\text { Conditioned } \\
\text { medium }\end{array}$ & $\begin{array}{l}\text { - Increased embryogenesis in explants } \\
\text { of responsive genotypes. } \\
\text { - Embryogenesis in explants of non- } \\
\text { responsive genotypes. }\end{array}$ & $\begin{array}{l}\text { Poon et al., } \\
2004\end{array}$ \\
\hline Zea mays L. & Arabic gum & $\begin{array}{l}\text {-Increased embryogenesis in low } \\
\text { responsive genotypes. } \\
\text { - No response in recalcitrant } \\
\text { genotypes. }\end{array}$ & $\begin{array}{l}\text { Boderies et al., } \\
2004\end{array}$ \\
\hline $\begin{array}{l}\text { Triticum } \\
\text { aestivum } \mathrm{L} .\end{array}$ & $\begin{array}{l}\text { Arabic gum } \\
\text { Larch wood } \\
\text { gum }\end{array}$ & $\begin{array}{l}\text { - Haploid plant production which was } \\
\text { otherwise impossible without an } \\
\text { ovary nurse culture. } \\
\text { - Reduced mortality of cultured } \\
\text { microspores. }\end{array}$ & $\begin{array}{l}\text { Letarte et al., } \\
2006\end{array}$ \\
\hline $\begin{array}{l}\text { Beta } \\
\text { vulgaris L. }\end{array}$ & $\begin{array}{l}\text { Conditioned } \\
\text { medium }\end{array}$ & $\begin{array}{l}\text { - Organogenesis in protoplast- } \\
\text { derived calli. } \\
\text { - Increased plant regeneration. }\end{array}$ & $\begin{array}{l}\text { Wisinewska } \\
\text { and Majewska, } \\
2007\end{array}$ \\
\hline $\begin{array}{l}\text { Daucus } \\
\text { carota } \mathrm{L} .\end{array}$ & $\begin{array}{l}\text { Cashew nut } \\
\text { tree gum }\end{array}$ & $\begin{array}{l}\text { - Increased somatic embryogenesis } \\
\text { and plant regeneration. }\end{array}$ & $\begin{array}{l}\text { Pereira-Netto } \\
\text { et al., } 2007\end{array}$ \\
\hline $\begin{array}{l}\text { Vitis } \\
\text { vinifera } \mathrm{L} .\end{array}$ & $\begin{array}{l}\text { Larch wood } \\
\text { gum } \\
\text { Conditioned } \\
\text { medium of } \\
\text { zucchini/ } \\
\text { parsley }\end{array}$ & $\begin{array}{l}\text { - Increased somatic embryogenesis } \\
\text { and plant regeneration from cell } \\
\text { suspensions. }\end{array}$ & $\begin{array}{l}\text { Ben Amar et } \\
\text { al., } 2007\end{array}$ \\
\hline $\begin{array}{l}\text { Cucurbita } \\
\text { pepo L. }\end{array}$ & $\begin{array}{l}\text { Conditioned } \\
\text { medium }\end{array}$ & $\begin{array}{l}\text { - Enhanced multiplication of slow } \\
\text { growing cell lines. }\end{array}$ & $\begin{array}{l}\text { Ben Amar et } \\
\text { al., } 2010\end{array}$ \\
\hline
\end{tabular}


Figure 1. Induction of somatic embryogenesis in plumule-derived callus of coconut. (a) Cultures with embryogenic structures (es) (x 4).

(b) Cultures with somatic embryos (se) (x 1.5)
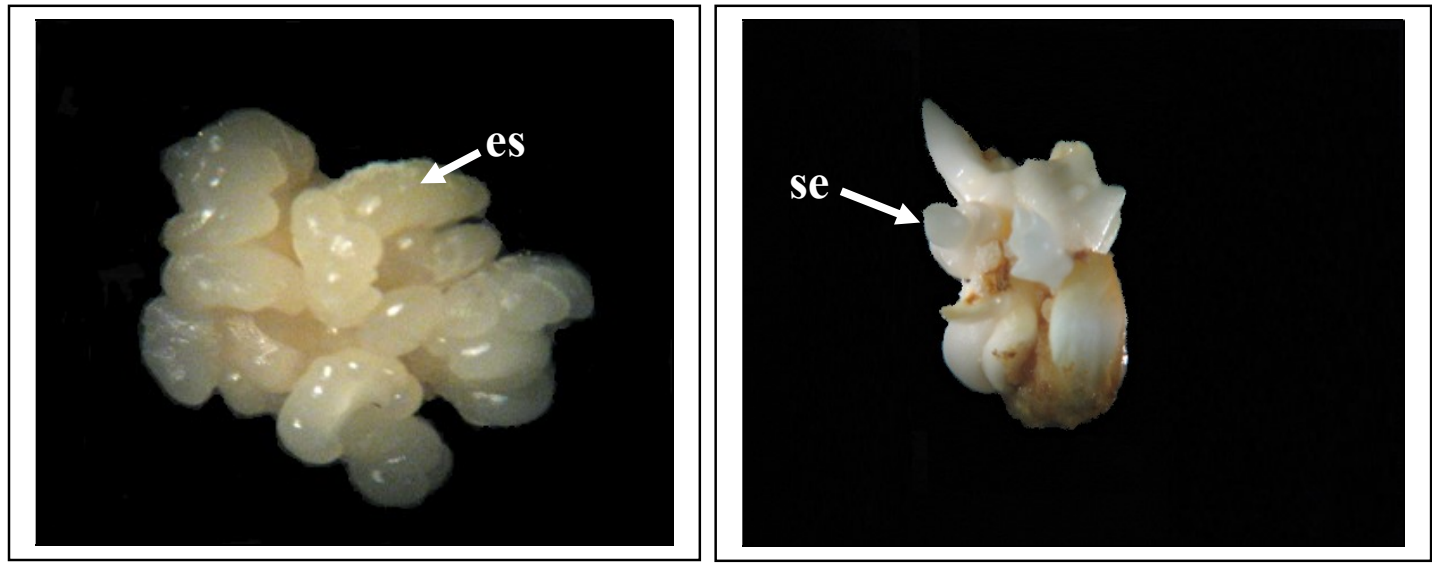

Figure 2. Effect of Arabic gum (AG) on initiation of callus from plumule explants of coconut

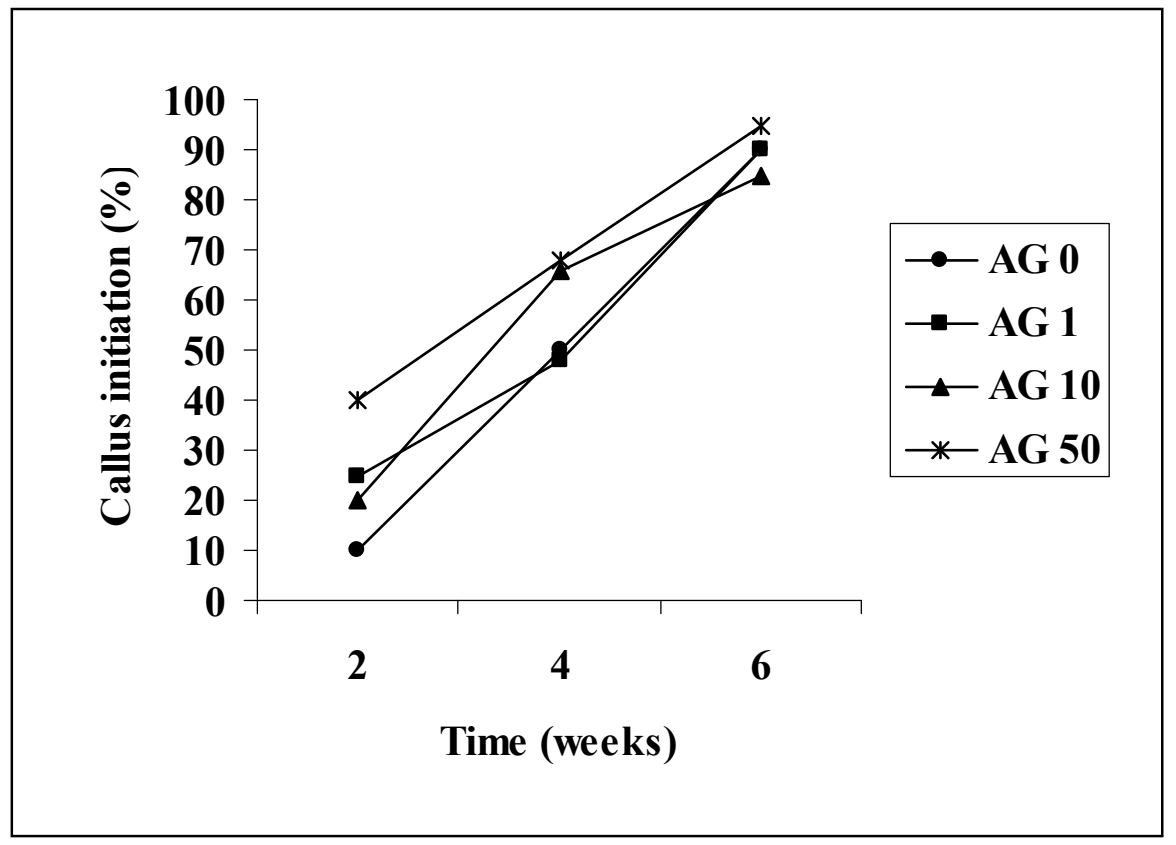


recorded to assess the effect of different AGP sources on somatic embryogenesis.

Difference between treatments was assessed using Logistic Regression Analysis in CatMod procedure in SAS software.

\section{Results}

The response of plumules cultured is shown in the Figure 2. The time taken to initiate callus varied among explants. The presence of $\mathrm{AG}$ in the medium resulted in early callogenesis in $20-40 \%$ plumules compared to $10 \%$ in the control. With the increase in AG concentration, the number of explants showing early callusing increased. However, the difference was statistically not significant. With time, the difference among callusing frequencies in media with varying levels of $A G$ disappeared and all treatments including control resulted in above 85$95 \%$ callusing explants after six weeks of culturing.

In this study, the effect of AGPs on embryogenesis was studied at two stages. Initially, the effect of $1-50 \mathrm{mgL}^{-1} \mathrm{AG}$ on embryogenic structure formation from plumule callus was assessed. The results revealed that the addition of AG had no significant improvement over the control in efficiency of forming cultures with embryogenic structures. However, it showed a significant increase in the mass of embryogenic structures formed per embryogenic clump (Table $2)$. The best results $(0.0505 \mathrm{~g}$ embryogenic structures per callus clump) could be seen at 10 $\mathrm{mgL}^{-1} \mathrm{AG}$.

At the second stage, the effect of various sources of AGPs on somatic embryogenesis was evaluated. As shown in the Figure 3, among the tested sources of AGPs, DCK at $25-50 \mathrm{mgL}^{-1}$ significantly improved the number of cultures producing somatic embryos $(70 \%)$ when compared to the control (37\%). Somatic embryogenesis in media containing other AGP sources like CS (25 and $\left.50 \mathrm{mgL}^{-1}\right)$ and AG (10 $\mathrm{mgL}^{-1}$ ) also showed an increase over the control but did not vary significantly. LW showed an inhibitory effect and the inhibition was significant at the level of $10 \mathrm{mgL}^{-1}$ when compared to the results of control.
At the stage of plant regeneration, a few shoots were developed from cultures irrespective of their AGP treatments. In the present study, the positive impact of AGPs on somatic embryogenesis did not reflect in plant regeneration efficiency.

\section{Discussion}

Callogenesis

Coconut (Sri Lanka Tall) plumules excised from pre-germinated mature zygotic embryos have shown to be potential explants for clonal propagation of coconut. The average callusing recorded was $50-60 \%$. The time taken to initiate callus varied from three to ten weeks. The variation in response of individual explants at least partially might be due to differences in maturity stage of individual explant (Fernando, 2001).

In the present study, overall performance of plumules was better and callusing recorded in six weeks of culturing was above $85-95 \%$ in all treatments. The improved response of plumules in the present study might be due to the use of plumules excised from freshly harvested embryos. In agreement with the study of Fernando (2001), in this study also explants needed varying time to initiate callus. However, application of AG resulted in early callusing in a higher number of explants compared to control.

AGPs are known to play an important role in in vitro development of tissues. Cells are surrounded by complex mixtures of AGP that are specific to tissue type and differentiation status (Kreuger and van Holst, 1995). Since the in vitro development of cells is influenced by the presence of specific AGP mixtures, explants with different degree of maturity might be under the influence of different AGP mixtures which might cause the variable response of explants. Under such circumstance, external application of AGP is an alternative approach to induce a controlled in vitro development.

Based on the results, it can be assumed that external application of AG readily created an optimum environment for more explants to induce callusing. However, explants in the 
Table 2. Effect of AG on initiation of cultures with embryogenic structures

\begin{tabular}{|c|c|c|}
\hline $\begin{array}{c}\text { AG LEVEL } \\
\left(\mathbf{m g L}^{-\mathbf{1}}\right)\end{array}$ & $\begin{array}{c}\text { CULTURES WITH } \\
\text { EMBRYOGENIC } \\
\text { STRUCTURES }\end{array}$ & $\begin{array}{c}\text { EMBRYOGENIC } \\
\text { STRUCTURES PER } \\
\text { EMBRYOGENIC } \\
\text { CLUMP (G) }\end{array}$ \\
\hline 0 (CONTROL) & 76 & $0.0269^{\mathrm{B}}$ \\
1 & 80 & $0.0333^{\mathrm{B}}$ \\
10 & 72 & $0.0505^{\mathrm{A}}$ \\
50 & 68 & $0.0396^{\mathrm{AB}}$ \\
\hline SIGNIFICANCE & NS & $*$ \\
\hline
\end{tabular}

$\mathrm{NS}=$ Not significant; $*=$ Significant at $\mathrm{p}<0.05$

Figure 3. Effect of different sources of AGPs on somatic embryogenesis in coconut plumule derived callus. AGP sources: control = Without AGP source, LW = Larch wood gum (1 and $\left.10 \mathrm{mgL}^{-1}\right), A G=$ Arabic gum (1 and 10 $\left.\mathrm{mgL}^{-1}\right), \mathrm{CS}=$ Carrot seed powder $\left(25\right.$ and $\left.50 \mathrm{mgL}^{-1}\right)$ and DCK = Defatted coconut kernel ( 25 and $50 \mathrm{mgL}^{-1}$ )

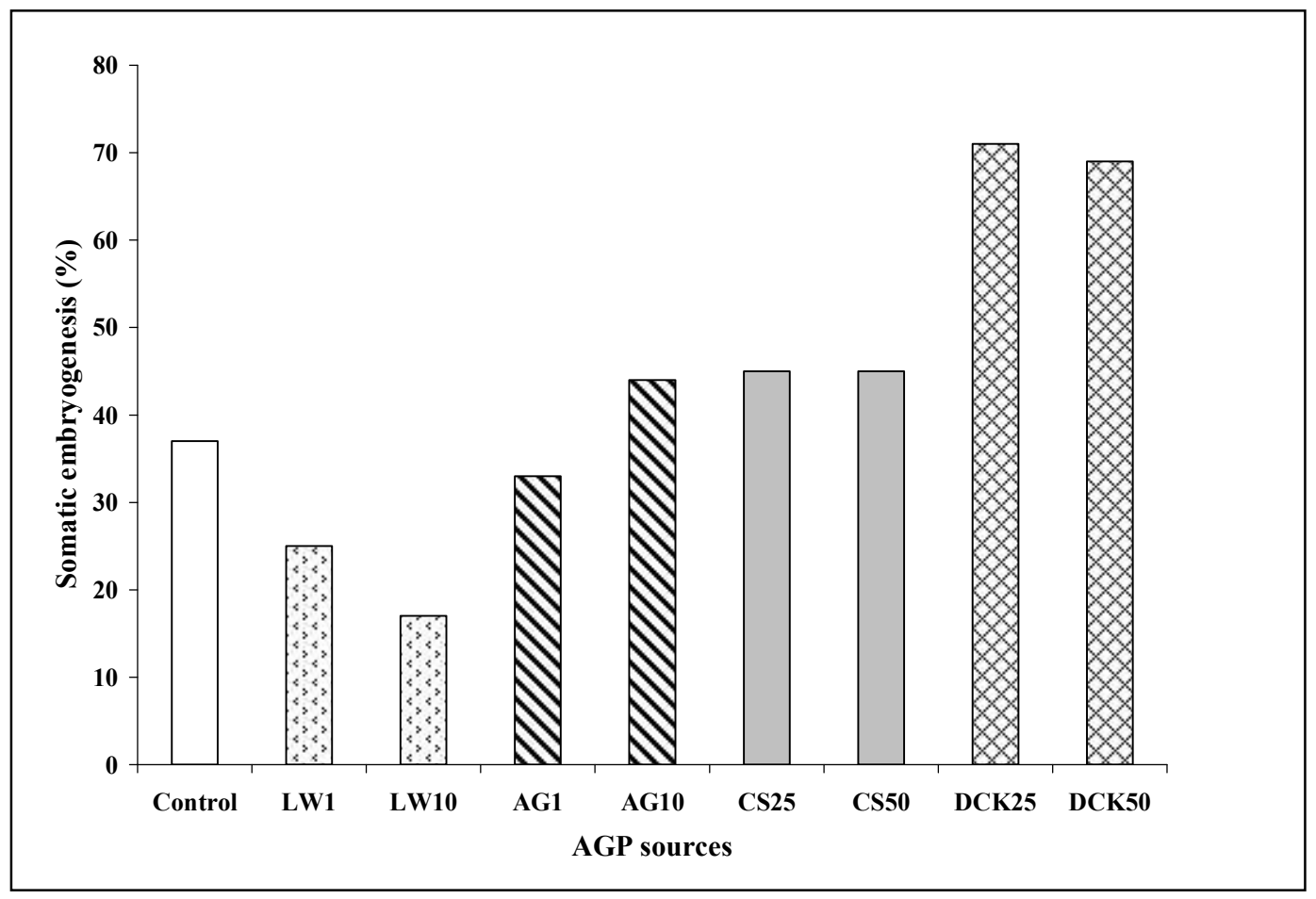


medium free of AG (control) also with time developed suitable conditions for callusing.

Somatic embryogenesis

Specific AGPs are essential for somatic embryogenesis (Kreuger and van Holst, 1993) and their presence or absence differentiates embryogenic and non-embryogenic/ weakly embryogenic lines (McCabe et al., 1997). Furthermore, the amount of specific AGPs in the environment also decides the embryogenic capacity (Poon, 2004).

In agreement with the previous studies, in this study, application of AG has shown increased embryogenic structure formation and the response was concentration dependant.

In the literature, evidence is available to support that the activity of AGPs is not species specific (Kreuger et al., 1995; Boideries et al., 2004; Letarte et al., 2006; Ben Amar et al., 2007). However, improved effect of species specific AGPs was also reported in grape (Ben Amar et al., 2007). This might be due to AGPs collected from a particular species are more suitable for cultures of the same species.

In the present study, when the effect of several sources of AGPs on somatic embryogenesis in coconut was tested, AGP sources improving somatic embryogenesis at different levels as well as inhibiting could be identified. DCK was found to be the best source used in this study and it might be due to the use of a coconut based AGP source.

However, in this study AGP extracted from DCK was not used to confirm the results. As coconut endosperm contains AGP (White et al., 1989), the improved response of DCK treated tissues might be at least partially due to AGP.

In this study, expected effect of AGPs on plant regeneration could not be seen. The modification of type, concentration, time and duration of application of AGP might be useful in optimizing culture conditions for improving clonal plant regeneration efficiency in coconut.

\section{Conclusion}

This study showed for the first time that the sources of AGPs play a positive role in different stages of clonal propagation of coconut. Arabic gum has the potential to induce early callusing and increase embryogenic callus formation from coconut plumules. Defatted coconut kernel extract have significant impact on somatic embryogenesis in coconut.

\section{Acknowledgements}

Authors acknowledge Dr Simon Poon, University of Melbourne, Australia and Dr Anne Blervacq, University of Lille, France for guidance and Head and the staff, Tissue Culture Division, Coconut Research Institute, Sri Lanka for all the assistance provided during the study.

\section{References}

Ben Amar, A., Cobanov, P., Boonrod, K., Krczal, G., Bouzid, S., Ghorbel, A. and Reustle, G.M. 2007. Efficient procedure for grapevine embryogenic suspension establishment and plant regeneration: role of conditioned medium for cell proliferation. Plant Cell Rep. 26:14391447.

Ben Amar, A., Cobanov, P., Ghorbel, A., Mliki, A. and Reustle, G.M. 2010. Involvement of arabinogalactan proteins in the control of cell proliferation of Cucurbita pepo suspension cultures. Biol. Planta. 54(2):321-324.

Borderies, G., Bechec, M., Rossigno, M., Lafitte, C., Le Deunff, E., Beckert, M., Dumas, C. and Matthys-Rochon, E. 2004. Characterization of proteins secreted during maize microspore culture: arabinogalactan protewins (AGPs) stimulate embryo development. Eur.J.Cell.Biol. 83:205-212.

Eeuwens, C.J. 1978. Effect of organic nutrients and hormones on growth and development of tissue explants from coconut (Cocos nucifera) and date (Phoenix dactylifera) 
palms cultured in vitro. Physiol. Planta. 42:173-178.

Egertsdoptter, U. and von Arnold, S. 1995. Importance of arabinogalactan proteins for the development of somatic embryos of Norway spruce (Picea abies). Physiol. Planta. 93:334-345.

Fernando, S.C. 2001. Studies on somatic embryogeneis of Cocos nucifera L. Ph.D. Thesis submitted to the University of Colombo, Sri Lanka.

Fernando S.C. 2008. Clonal propagation of coconut: prospects and limitations. Proceedings of the 2nd Symposium on Plantation Crop Research. October 2008, Colombo, Sri Lanka. pp. 322-326.

Fincher, G.B., Stone, B.A. and Clarke, A.E. 1983. Arabinogalactan proteins; structure, biosynthesis and function. Annu. Rev. Plant Physiol. 34:47-70.

Karunaratne, S., and Periyapperuma, K. 1989. Culture of immature embryos of coconut, coconut, Cocos nucifera L.: callus proliferation and somatic embryogenesis. Plant Sci. 62:247-253.

Kreuger, M. and van Holst, G-J. 1993. Arabinogalactan proteins are essential in somatic embryogenesis of Daucus carota L. Planta 189:243-248.

Kreuger, M., Postma, E., Brouwer, Y. and van Holst, J-G. 1995. Somatic embryogenesis of Cyclomen persicum in liquid medium. Physiol. Planta. 94:605-612.

Kreuger, M. and van Holst G-J. 1995. Arabinogalactan-protein epitopes in somatic embryogenesis of Daucus carota L. Planta 197:135-141.

Letarte, J., Simion, E., Miner, M. and Kasha, K.J. 2006. Arabinogalactans and arabinogalactan-proteins induce embryogenesis in wheat (Triticum aestivum L.) microspore culture. Plant Cell Rep. 24: 691-698.

McCabe, P.F., Valentine, T.A., Forsberg, L.S. and Pennell, R.I. 1997. Soluble signals from cells identified at the cell wall, establish a developmental pathway in carrot. Plant Cell 9:2225-2241.

Pennell, R.I., Janniche, L., Scofield, G.N., Booij, H., De Vries, S.C. and Roberts, K. 1992. Identification of a transitional cell state in the development pathway to carrot somatic embryogenesis. J. Cell Biol. 119:13711380 .

Pereira-Netto, A.B., Pettolino, F., Cruz-Silva, C.T.A., Simas, F.F., Bacic, A., CarneiroLeao, A.M.D.A., Iacomini, M. and Maurer, J. B.B. 2007. Cashew-nut tree exudates gum: Identification of an arabinogalactan protein as a constituent of the gum and use on the stimulation of somatic embryogenesis. Plant Sci. 173:468-477.

Poon, S., Clarke, A. and Heath, R. 2004. Improving the efficiency of embryogenesis in elite cotton cultivars. Paper presented at the $12^{\text {th }}$ Australian Cotton Conference, Gold Coast.

Van Hangel, A.J., Tadesse, Z., Imeerseel, P., Schols, H., van Kammen, A. and De Vries, S.C. 2001. N-acetylglucosamine and glucosamine containing arabinogalactan protein control somatic embryogenesis. Plant Physiol. 117:43-53.

White, A.R., Elmore, H.W., Watson, M.B. and Gill, J.P. 1989. Purification and partial characterization of polysaccharides from coconut milk. Annals of Botany 64:205209.

Wisniewska, E. and Majewska-Sawka, A. 2007. Arabinogalactan-proteins stimulate the organogenesis of guard cell protoplastsderived callus in sugar beet. Plant Cell Rep. 26:1457-1467. 